\title{
THE ETHICS OF FICTIONALITY IN HISTORY WRITING ${ }^{1}$
}

\author{
LA ÉTICA DE FICCIÓN EN LA ESCRITURA DE LA HISTORIA \\ A ÉTICA DA FICÇÃO NA ESCRITA DE HISTÓRIA
}

\author{
Kalle Pihlainen \\ (University of Turku) \\ kalle.pihlainen@utu.fi \\ Recibido: $11 / 12 / 2020$ \\ Aprobado: 08/01/2021
}

\begin{abstract}
Fictionality has long been viewed in history writing as near-synonymous with abandoning truth and any supposedly consequent, ethical commitments. Understandably, this attitude has impeded the acceptance of theoretical approaches that aim, instead, to reveal the fundamental connectedness of history's fictional aspects with ethical concerns. This line of thought is nowhere more evident than in the reception of Hayden White. While instrumental in arguing for the similarities between history writing and literary fiction, White has also consistently defended the vital importance of rethinking history's fictionality. His approach considers that historians might work in more consciously emancipatory and ethically informed ways. This article seeks to improve understanding of White's complicated position in two distinct ways: firstly, by rehearsing his critical arguments in the context of their general and far-too-often hostile reception; here, the main goal is to address worries relating, in turn, to the claimed extreme textualism, the assumed denial of reality and the supposedly excessive formalism of his positions. Given the generational demand for reiterating these basics, some of this discussion may prove familiar to readers for whom White's place is already evident. Secondly, the article hopes to contribute to the continuation of White's legacy by indicating a way to by-pass these controversies through a reconceptualization of White's ethical objectives and the responsibility he attributes to historians. This view includes examining an unwarranted tension between interpretations of White's existentialist and poststructuralist commitments in previous readings. The article also identifies the point at which the overlap of these aspects constitutes his expressly ethically motivated relativism.
\end{abstract}

Keywords: ethics of history. fictionality. Hayden White. reception. poetics of history

\section{RESUMEN}

La ficción en la escritura de la historia ha sido considerada durante mucho tiempo como casi sinónimo de abandono de la verdad y de cualquier compromiso ético supuestamente consecuente. Es comprensible que esta actitud haya impedido la aceptación de enfoques teóricos que pretenden, en cambio, revelar la conexión fundamental de los aspectos ficticios de la historia con las preocupaciones éticas. En ninguna parte esto es más evidente que en la recepción de Hayden White, quien, si bien contribuyó decisivamente a defender las

\footnotetext{
${ }^{1}$ My appreciation to Keith Jenkins and María Inés La Greca for their close reading and, as always, valuable suggestions. Many thanks for ideas and advice also to Daniel Fulda who - in the role of editor of a forthcoming German-language companion to literature and history commissioned from me the entry on Hayden White, on which this article expands.
} 
semejanzas entre la escritura histórica y la ficción literaria, también ha defendido consistentemente la importancia vital de repensar la ficcionalidad de la historia para que los historiadores puedan trabajar de manera más conscientemente emancipadora y formas éticamente informadas. Este artículo busca mejorar la comprensión de la compleja posición de White en dos aspectos distintos. En primer lugar, ensayando sus argumentos clave en el contexto de su recepción general y demasiado a menudo negativa. Aquí el objetivo principal es dirigir las preocupaciones relativas, sucesivamente, al pretendido textualismo extremo, la presunta negación de la realidad y el supuestamente excesivo formalismo de sus posiciones. Dada la demanda generacional de reiterar estos conceptos básicos, parte de esta discusión puede resultar familiar a lectores para quienes la posición de White ya esté clara. En segundo lugar, el artículo espera contribuir a la continuación del interés en el legado de White al indicar un modo de eludir estas controversias a través de la reconceptualización de los objetivos éticos de White y de la responsabilidad que atribuye a los historiadores. Esto incluye examinar en las lecturas previas la injustificada tensión entre las interpretaciones de los compromisos existencialistas y postestructuralistas de White e identificar el punto en el cual estas superposiciones constituyen su relativismo expresamente motivado por la ética.

Palabras clave: ética de la historia. ficción. Hayden White. recepción. poética de la historia

\section{RESUMO}

A ficção na escrita da história há muito é considerada quase sinônimo de abandono da verdade e de qualquer compromisso ético supostamente consequente. Compreensivelmente, essa atitude impediu a aceitação de abordagens teóricas que procuram, em vez disso, revelar a conexão fundamental dos aspectos ficcionais da história com as preocupações éticas. Em nenhum lugar isso é mais evidente do que na recepção de Hayden White, que, embora instrumental na defesa das semelhanças entre a escrita histórica e a ficção literária, também defendeu consistentemente a importância vital de se repensar a ficcionalidade da história para que os historiadores pudessem trabalhar de maneiras mais conscientemente emancipatórias e eticamente informadas. Este artigo busca melhorar a compreensão da complexa posição de White de duas maneiras diferentes. Em primeiro lugar, ensaiando seus principais argumentos no contexto de sua recepção geral e, muitas vezes, negativa. Aqui o objetivo principal é abordar preocupações relativas, sucessivamente, ao alegado textualismo extremo, à alegada negação da realidade e ao formalismo supostamente excessivo de suas posições. Dada a demanda geracional para reiterar esses conceitos básicos, parte desta discussão pode ser familiar a leitores para os quais a posição de White já está clara. Em segundo lugar, o artigo espera contribuir para o interesse contínuo no legado de White, indicando uma maneira de contornar essas controvérsias por meio de uma reconceitualização dos objetivos éticos de White e da responsabilidade que atribui aos historiadores. Isso inclui examinar em leituras anteriores a tensão injustificada entre as interpretações de White dos compromissos existencialistas e pós-estruturalistas e identificar o ponto em que essas sobreposições constituem seu relativismo expressamente motivado pela ética.

Palavras-chave: ética da história. ficção. Hayden White. recepção. poéticas da história.

The debate over history's relation to fiction is long-standing among historians and continuously resurfaces also in connection with efforts to explicate the nature of history within the theory and philosophy of history. Yet it is, most often, established in a fear of the ethically debilitating effects of a marginalization of truth and reference and concludes in a denial of the possibilities of fictionality. In the face of this almost reflex response, no-one has done more to illuminate the fictional practices involved in history writing than Hayden White. But even White's interventions have been largely received as relating to matters of truth and reference, and their finer points and explicit ethical impetus ignored. Against this background, my aims here are twofold: 
First, to offer a selective reading of the reception of White, including what I take to be its core failures. This involves trying to approach White's interventions "innocently" as it were, without coming to him exclusively through a close theoretical reading, but instead attempting to take into consideration the objections even in those critiques that have perhaps not always been directed at understanding the core point of his efforts. Examining the reception in this way, going outside the narrow field of theory and philosophy of history where much thoughtful reading has been carried out, suggests that many readers have either assumed White to ultimately be making metaphysical and ontological claims about reality and the past (rather than speaking, far less grandiosely, as he mostly does, about historians' professional attitudes and the nature of historical texts) or they have read him as gesturing at methodological tools to be put to use in reconceiving history. In these connections, he has been viewed variously as a defender of linguistic "free play" and the absolute "fictionality" of history, as a nihilist denier of "reality" and, perhaps somewhat contradicting these other interpretations, as advocating formal rules to be applied in the textual analysis of historical works. To balance a reading of such criticisms, it is obviously important to also present White's own arguments as clearly as possible; in doing this, I quote him directly wherever possible, before going on to offer my own gloss on his ideas.

Second, following this situating of White's work among the broader readership, much of which has ultimately chosen to ignore or, in the best-case scenario, to attempt to "apply" it, I attempt to articulate what I see as the core philosophical commitments at play in his thinking. While White has obviously been open to influences from numerous directions, I concentrate on two key strands, the intimate relation between which I feel has not been sufficiently appreciated to date; these two are White's existentialism (appealed to by commentators quite often) and his poststructuralism (in my opinion, only superficially touched upon in readings of White, and usually seen as being incommensurable with his general position). Important here is the way in which these two inform his specific brand of ethically motivated relativism. In this examination, and by way of conclusion, I go on to defend this particular reading of White's commitments as well as to specify the precise nature of the core "ethics" that this mixed philosophical inheritance leaves us with, assuming that we wish to continue to advance what might here be labelled a "Whitean" and "constructivist" project regarding history writing.

For purposes of full transparency, I should make clear that my motivation for approaching the current moment in historical studies and the role of constructivism in their future development in this way results from a combination of my appreciation for White's ground-breaking work and a fear that these insights have still not been given the consideration they deserve. Instead, it seems that many misapprehensions about the consequences persist and historians largely continue to avoid the related theoretical debates. White, for his part, has made this point forcefully, claiming that "[m]any historians feel that historical studies have no need of a theory or theories of history because 'history' is what historians do. [...] their practice constitutes sufficient 'theory' for their work" (White, 2017: xi).

When I first began to work on practices of historical representation - undisturbed by such pessimistic views of the history profession's openness to change and firmly in the "linguistic turn" context of the 1990s - White's insights appeared to point to radical opportunities in many disciplinarily exciting directions. Even today, they continue to hold promise for freeing historians from a belief in naive entailments of meaning from reality and can make us better aware of the personal responsibility for the consequences of historical work and interpretation as well as of the importance of conscious decisions regarding history's representational form. Particularly in this ethical direction, White's oeuvre and insights continue to hold great unrealized potential and, proceeding from where he brought the debate, can still provide an excellent opportunity for (re-)thinking history practices. So far, opposition has been strong, however, and the radical impetus of White's thought has been exhausted by the need to repeatedly revisit more basic questions. ${ }^{2}$ Rather than contributing to a constructive project in relation to historical

\footnotetext{
${ }^{2}$ The strategy of White's critics to always turn attention back to simplistically conceived epistemological considerations (reality, reference, truthfulness, accuracy and so on) seems at least partially responsible for the fact that the views of more radical advocates of a reformulation of historical representation - figures like Keith Jenkins, willing to take things "to the end of the line" (White, 2009: 1), or Sande Cohen (equally committed in Cohen, 1993, for example) - have remained marginal. In my own work, too, commentators have pointed to a shift from pursuing the more radical implications of a Whitean position to instead countering misreadings of his basic claims in ever greater detail; see Roth (2020a) and Fillion (2019); cf. Pihlainen (2017).
} 
writing and representation, the continued resistance to White's fundamental claims serves to reset discussions - primarily returning them to the perennial controversy regarding "history as fiction," but also to concomitant fears that accepting such a "literary" view of history opens the door to a dreaded relativism or even nihilism regarding broader societal values. ${ }^{3}$ To outline the route that opposition commonly takes, and at the cost of rehearsing parts of the "old" discussion, it is important, once more, to begin by attending first to these concerns over history's fictionality.

\section{History as "free play" and other fictions}

As I see it, the key failure in the reception of White's work - and the key controversy that routinely surfaces in relation to it - is typically marked by the ostensibly polemic question "is history fact or fiction?" Naturally, this question serves to draw the battle lines for those willing to fight over it, but at the same time it prevents any more involved investigations into the nature of history as representation. Furthermore, it completely disregards volumes of sophisticated philosophical and literary theory inquiries regarding fiction and fictionality. Yet, even for theoretically sensitive historians like Georg Iggers, for instance, this issue constituted the core objection against White as late as 2000. Iggers' understanding of the matter, as expressed in a visible exchange with White, serves to illustrate the common perception exceptionally well, and a detailed examination of it is instructive. Iggers summarizes his reading of White in the following way:

In my opinion White's error is that he argues that because all historical accounts contain fictional elements they are basically fictions and not subject to truth controls. For him there are not only many different possible accounts of any set of events and interpretations of any set of documents, but all of them have the same truth value. (Iggers, 2000: 383)

Now, on the face of it, this sounds like a convincing enough argument, and it is easy to see why historians would reject White on such a view. If indeed White's position is that truth controls do not apply in any way to historical representation, it obviously runs afoul of most disciplinary and professional justifications for continuing to write history. And, admittedly, White has made various provocative statements that can be read as hinting at this - as Iggers has done here. ${ }^{4}$ For example, in what perhaps constitutes his most famous pronunciation relating to the fictionality of history (in what to me is also his most important essay, "The Historical Text as Literary Artifact"), White quite bluntly states: "Historians may not like to think of their works as translations of fact into fictions; but this is one of the effects" (White, 1978: 92). The explanation for why such "translation" is unavoidable is less commonly cited, however: "By the very constitution of a set of events in such a way as to make a comprehensible story out of them, the historian charges those events with the symbolic significance of a comprehensible plot structure" (White, 1978: 91-92). In other words, by imposing a comprehensible structure through their practices of emplotment and storying, historians introduce meaning and significance (what else could make something "comprehensible," after all?).

Instead of leading to unreasonable views of history's fictionality, then, what this understanding of the construction of meaning suggests is that - although the kind of "truth" that Iggers and like-minded critics are after can be counted as a basic consideration in establishing historical facts - other criteria (for example, and classically, the concept of "validity" or even an appeal to consequences) can be better applied in evaluating more involved and extended textual constructs. ${ }^{5}$ The extreme claim that all possible

\footnotetext{
${ }^{3}$ For two recent accounts of White's reception in relation to the perceived dangers of this progression to relativism, see Roth (2019) and Pihlainen (2019b). A brief overview of key literature on White can be found in Ball and Domańska (2019).

${ }^{4}$ Frank Ankersmit (2009: 37) claims, even more forcefully, that "White himself provided his enemies with the ammunition that they often used against him so effectively." Likewise, in a reading that is largely critical of White, David Roberts (2013: 276) generously notes that "the potentially productive side of White's challenge" was largely rejected by historians because of his "mischaracterization" and "overstatement" of the problems of historical work.

${ }^{5}$ Many critics seem to lack the basic understanding that "truth value" is typically conceived of as a property of individual statements, not of arguments or extended emplotments, which are better judged in terms of their validity. White's position on truth and reference is undoubtedly the most contested issue in the broader reception. Arnaldo Momigliano famously objected to White's approach "because he has eliminated the research for truth as the main task of the historian” (Momigliano, 1981: 259; see also Southgate, 2003 : 17 and Burke,
} 
accounts hold the same "truth value" for White is in fact contradicted by his arguments and thus introduces significant confusion when we seek to understand the constructivist position. It is clear that Iggers has read White on the matter, yet, like so many others, fails to fully appreciate the precision of the argument. As he correctly cites, White's claim is that, "[v]iewed simply as verbal artifacts, histories and novels are indistinguishable from one another" (Iggers, 2000: 384; White, 1978: 122). Tellingly, though, Iggers ignores the crucial qualification "simply" here, assuming instead - like so many readers of White who take him to be advocating a view of "history as fiction" - that this parallel should rather be applied to all aspects, including any "truth value" that he would insist on also with respect to these extended, more complex representational forms.

A great deal hinges on this seemingly innocent and marginal point of what history as a "verbal artifact" simpliciter might be, and elaborating on it serves well to dissect the overall conflict concerning fictionality. Responding directly to Iggers' reading, White clarifies his position further, recognizing that "Iggers says that I err in not considering historians' intentions." However, White stresses that, for him, "when we are concerned with the history of historical writing, it is the intentions of the text that should interest us, not the intentions of the writer." (White, 2000: 406). Against this, Iggers' intuition and follow-through are revealing of the way the idea of "simply" the text is easily, and most-often unwittingly, broadened out in an immediate segue to the non-textual: it strikes Iggers as obvious that "in truth only writers have intentions" (Iggers, 2000: 378); and he thus interprets White's suggestion to read texts in this way - first and foremost on their own terms, as it were - as a turn to some absurd textualism:

if we exclude the author's intentionality from the text and refrain from asking questions seeking to probe his/her intentionality, we are forced to take an absurdist notion of free play which permits the texts to be interpreted in an infinite number of ways (Iggers, 2000: 378).

Disregarding for a moment the questionable legitimacy of the jump from authorial intention to reader interpretations (the difficulty of which Iggers seems in fact to partially consider, noting that, "of course, the author may not be fully conscious of the implications of his writing" [Iggers, 2000: 378]), there is a far more significant problem in evidence here: even in radical textualist approaches, readings are constrained by the linguistic commitments and practices and cultural codes and endowments that inform us both as writers and as readers. "Free play" in this extreme sense is a scarecrow, invoked to sidestep discussions about the challenges of reference, as indeed is the attendant formulation of immoderate textualism that Iggers attempts to pin on White. ${ }^{7}$ According to Iggers (2000: 378), "[t]he textual approach assumes that the text can be read without reference to a referent"; yet, at most, this would only hold for referential texts only as long as they are read "simply as verbal artifacts" - when read as verbal artifacts belonging to a specific referential genre and with specific referential commitments, as histories by definition do, this is clearly not the case. This articulation underlines the fact that the constructivist claim is not directed at reference as such, but at mediatedness and the limits of our knowing: even specifically referential texts fail to provide access to reality. Rather, a historical text simultaneously assumes and constructs its referent; and its explicitly referential genre expectations (as, in practice, expressed in historians' intentions) ensure that historians as authors demonstrate fidelity to their professional commitments - which are far from unclear in this respect. But none of this means that the commitments themselves, or some "intentions," need to be "read back" from the text; instead they are

\footnotetext{
2013: 440). Similar objections have been raised most notably - and in order of their initial appearance - by Carlo Ginzburg (1992), Gertrude Himmelfarb (1997), Roger Chartier (1997) and Arthur Marwick (see White's [1995] response to this). Likewise, for readers such as Gabrielle Spiegel, White's point was to argue for "historical narrative as intrinsically no different than fictional narrative, except in its pretense to objectivity and referentiality" (Spiegel, 1997: 278, my emphasis; see also Vann, 1998: 156). In a thorough account of White's reception Richard Vann, however, regards all such claims as misinterpretations for the simple reason that White, "notoriously, has bracketed considerations of historical knowledge, as he has bracketed treatments of the referentiality of language" (Vann, 1998: 143). This well summarizes the reading that I defend here too.

${ }^{6}$ White makes this point unambiguously with respect to history: "The historian shares with his audience general notions of the forms that significant human situations must take by virtue of his participation in the specific processes of sense-making which identify him as a member of one cultural endowment rather than another" (White, 1978: 86). For more on this, see Pihlainen (2017: 101-102; 2019a).

${ }^{7}$ As Nancy Partner (1998: 171) instructively reminds, recognizing the role of the textual intention in the presentation of truth-claims is a strategy that "would be stable, intelligible, and defensible against extreme relativist attack" without need to "make claims to extra-linguistic transcendence."
} 
already in it as textual consequences and are a core part of the overall genre expectation for the reader too (for a detailed elaboration of arguments relating to this process, see Pihlainen, 2019a).

In later work, White recognizes that, despite the overwhelming success his provocations had in bringing to the fore questions of fictionality and constructedness, and, by extension, on occasion, also the broader societal responsibility of historians, they also negatively influenced the reception of his more involved argument. With the help of hindsight, in the introduction to The Practical Past, he suggests that it might have been better to communicate his understanding of "fiction" more explicitly:

I had failed to make clear that by the term "fiction" I had had in mind Jeremy Bentham's conception of it, as a kind of invention or construction based on hypothesis rather than a manner of writing or thinking focused on purely imaginary or fantastic entities. (White, 2014: xii) ${ }^{8}$

This belated concession may perhaps have been more for purposes of facilitating dialogue than of owning up to having in fact been "misleading," though, since there is little room for confusion for those who choose to read White closely. After all, he reminds readers of the importance of historians' referential commitments throughout his work: for example, by emphasizing the obligation of "properly" assessing truth value with respect to the facts (or "singular existential statements") comprising a historical representation "taken individually" rather than in relation to "the logical conjunction of the whole set of such statements taken distributively" (White, 1987: 45; see my footnote 5 here). In this connection, he importantly underscores that, "unless a historical discourse acceded to assessment in these terms, it would lose all justification for its claim to represent and provide explanations of specifically real historical events" (White, 1987: 45). Even in his most vehemently rejected provocations designating histories as "verbal fictions," he is similarly cautious to qualify them as being "as much invented as found" (White, 1978: 82; my emphasis). ${ }^{9}$ So much for any alleged nihilist "free play" with regard to historians' professional commitments at least.

\section{Realist intuitions and desires}

Whatever White's precise motives for the proffered accommodation of criticism in The Practical Past, this could reasonably be expected to mitigate the desire to return to the issue of fictionality in the future - assuming sympathetic readers going forward, of course. The contested difference - the main point on which the opposing ways of understanding the place of fictionality in history fail to agree - is formulated succinctly by White in response to Iggers, and it centres on the role of those "elements" of a complex representation that go beyond the basic facts (most obviously structural decisions, rhetorical tropes, emplotments, plot points and so on):

\footnotetext{
Where we differ is in our conceptions of the discursive functions of these elements. He [Iggers] thinks they are decorative or matters of style. I think they are constitutive, not of reality, but of the meanings with which historians endow the facts of the past by narrativization. (White, 2000: 406)
}

Understanding this difference is particularly important because even formulations that try to take the qualifications made by White into consideration and respond with modulated, less polemicizing questions (something like, for example: "to what extent, then, should we consider history to be fictional?") continue to invite accusations of relativism and antirealism. If history is taken as "fiction" in any sense of make-believe, of being completely detachable from reference, if, that is, it is seen as

\footnotetext{
${ }^{8}$ Of course, this understanding of fictionality should have been obvious at least to contemporaneous readers since it had been pointedly discussed at the time; prominently by Clifford Geertz (1973: 15-16), for whom "fiction," following "the original meaning of fictio," implied "something fashioned" rather than some "false, unfactual, or merely 'as if' thought experiments." The reasonableness of this expectation is borne out by Spiegel, for example, who notes the simultaneous reception of Geertz's Interpretation of Cultures with White's Metahistory, along with their shared reliance on Northrop Frye (Spiegel, 2013b: 172).

${ }^{9}$ Although White's claims are closely delimited, objections continue to be presented along the same, expansive routes; for example, Bernard Waites claims of a particular book in economic history that "it would be perverse to label the book a 'verbal fiction' or 'theoretical construct' with no referent in historical experience" (2011: 322; my emphasis). Why does this issue of reference always appear as if a natural supplement to White's precise formulations? In the same piece and along the same lines, Waites also finds it necessary to object to the exaggerated, spurious idea that the past is “"invented” by intellectuals” (2011: 326).
} 
being unconstrained by beliefs about reality and reference, the simplistic reception will continue to be that a Whitean position refutes the existence of reality itself rather than, less ambitiously, that it denies the possibility of situating comprehensibility and meaning in that reality to be discovered or "found" there by the historian. Now, while such a chain of thought is wildly generalizing and makes a number of illegitimate jumps, it is not uncommon, and is reinforced by the habitual intuition that "history" and "the past" should essentially correspond.

In a formative article on White, Keith Jenkins goes to great lengths to make clear that the constructivist stance is not one of antirealism in the sense of denying reality, but instead hinges on the issue of accessibility and meaning. As Jenkins explains his adoption of the commitments involved: "I take as my originary axiom the existence of matter; of materiality, of 'actuality.' I take it that the 'stuff' we call, for example, the world, the universe, etc., is really out there and is therefore not the product of my current mental state." But, he continues, "I hold the view (with Richard Rorty) that whilst the 'world' is 'out there' meanings are not; that whilst the world is 'out there' truths are not, since meanings and truths are in sentences and sentences are not 'out there." (Jenkins, 2008: 60; reprinted as Jenkins, 2009, with minor modifications). Despite this and other equally unambiguous qualifications, opponents have, however, continued to read constructivist attempts at detaching meaning from reality along these lines as signifying a denial of the existence of reality itself (and, obviously, in the case of debates in theory of history, specifically of past reality). ${ }^{10}$ For example: in response to this essay by Jenkins on White, and already in the abstract to his article, Bernard Waites feels the need to stress that very issue: "I defend the 'realist' view that the historical past existed independently of our present knowledge and thinking about it" (Waites, 2011: 319). What is more, it is "correspondence with the independent reality of the past" (Waites, 2011: 327) that makes possible his particular kind of realism. Affirming that such readings of White are not merely isolated examples but persist in - if not indeed currently even dominate - the discipline, Gabrielle Spiegel (2019: 4) has recently observed a strengthening trend within the profession to "reject the sort of encompassing narrativism associated with Hayden White's Metahistory as 'antirealist' and therefore standing in contradiction to history's primary goal of gaining legitimate and authentic knowledge of the past."

There is little doubt, then, that focus on empiricism and the idea of correspondence of some kind is firmly lodged in general intuitions regarding how history should be approached. What is more, it often involves the elision of "history" with "the past" already at the level of terminology - sometimes even in otherwise quite sophisticated philosophical proposals. When beginning to introduce his preferred terminology of "philosophy of historiography" in 2001, Aviezer Tucker, for instance, repeatedly and quite pointedly stresses the need to distinguish "historiography" from "history," as if history were the reference for historians' investigations and, as such, somehow synonymous with the past. ${ }^{11}$ It is particularly in conjunction with such stubborn intuitions and assumptions that the difficulties with realism are also manifested: if "history" and "the past" are conflated already in our terminology, the separation of the representational aspects of stories from "reality" also becomes that much harder. This is a terminological issue that defenders of White like Jenkins as well as Alun Munslow have been especially vocal in

\footnotetext{
${ }^{10}$ There is significant variance among the ways in which the terms "realism" and "antirealism" are used in these debates, and even close readers of White differ in their vocabularies. Paul Roth, for example, employs "realism" in a different sense to Jenkins' usage, or indeed to mine here; roughly as signifying the expectation that reality can entail meanings. (And Roth further introduces the concept of "historical irrealism" to counter "realist" metaphysical assumptions of meaning as somehow "out there"; Roth, 2020b: 35.) Regardless of the terminological differences, Roth identifies the core problem in the same way: for him, too, the crucial point of White's work is to urge historians "to drop the pretense that they tap into sources of authority that magically transcend the cultural fray" (Roth, 2019: 543). In this effort, he terms White an "anti-realist," however, since "realism," in the sense of reality providing some transcendental grounds, "is to be rejected because it only serves to license an intellectual and moral position that historians have no right to claim" (Roth, 2019: 543). So, importantly, meanings and justifications are not in reality according to his reading either.

${ }^{11}$ Or perhaps Tucker means by "history" the study of past events, in which case his comparison of the relationship between "historiography" vs. "history" to "science" vs. "nature" in this connection is misleading; likewise, Tucker's appeal to the inevitability of some "synthetic" aspect in all propositions suggests that "history" here intends, rather, a concrete referent. It seems safest to cite him directly on this and to let readers decide: "Philosophers, like everyone else, have reliable access to history only through historiography. These philosophers of history perforce must deal with historiography (approximately, what critical historians write). I do not mean to imply that philosophers of historiography can deal exclusively with historiography and ignore history, any more than philosophers of science can ignore nature; Quine's destruction of the analytic/synthetic distinction precludes such a Kantian conceptual-analytical division of labor. But I do mean that when philosophers consider history, they must do so through and in relation to historiography. To distinguish this new kind of philosophy of history, I call it the philosophy of historiography." (Tucker, 2001: 48)
} 
emphasizing, but also one that White has himself on occasion sought to elucidate. In summarizing his disagreement with Iggers, for instance, White notes this explicitly:

Iggers seems to think I have not understood that (modern) historians are interested in making true statements about "the past" and "history" (I make a distinction between the two), that they wish to deal in "facts" and not "fictions," that they are interested in finding facts and do not wish to invent them, and that their writing is intended to be a contribution to "scholarship," and not to "literature." (White, 2000: 405)

White has not always been consequential with this distinction, however (and the clarification here is another example of why the exchange with Iggers is so instructive). Instead, less precise formulations even in connection with the controversial provocations cited in the previous section may have encouraged some of the extreme reactions discussed. ${ }^{12}$

The reason to dwell on the terminology here is that the move from linking "the past" to "history" in this way - as if a natural correspondence existed - to assuming realism in representation as being something more fundamental than just another literary device ${ }^{13}$, to then also assuming metaphysical (and often specifically moral) entailments somehow being carried over from reality into the story form, contributes significantly to the overall difficulty of accepting the challenges of meaning-making in historical representation. There are also crucial practical and disciplinary reasons for this tendency, of course, and these align with the basic realist intuitions of historians. Centrally: for other, non-historical genres, presenting history as an ultimately "realist" endeavour aids in thinking about and refining their own practices ${ }^{14}$; relatedly, being able to distinguish between history and propaganda or "ideology" in an unproblematic way would bolster the authority of the discipline. Given this general predisposition, White's claim that attending to the literary or "fictive" side of history writing would help expose the ideological commitments involved is, understandably, more easily ignored than welcomed for its critical potential. But, for White, the importance of this insight is obvious: "this recognition would serve as a potent antidote to the tendency of historians to become captive of ideological preconceptions which they do not recognize as such but honor as the 'correct' perception of 'the way things really are" (White, 1978: 99).

Unfortunately, even when the "ideological" or "rhetorical" dimension of historical representation is accepted as inevitable and formative to some extent (as opposed to superfluous and "decorative" as White finds it to be in Iggers' perception discussed above at least), there often appears a tendency to simplify what is meant by "narrative" and "narrativization" in the context of history writing. And this simplification, too, relates to the difficulty of accepting the lack of a meaningful link with reality as well as the underlying assumption that merely being "realistic" and somehow "authentic" will keep us safe from ideological "distortions." A central and surprisingly popular reading of "narrativity" in such a limiting sense can be found in David Carr's influential argument against White and other representatives of what Carr (aptly) calls the "discontinuity view" - the idea that narratives are discontinuous with reality. For Carr, this view is mistaken. Rather, he argues: "Narrative is not merely a possibly successful way of describing events; its structure inheres in the events themselves. Far from being a formal distortion of the events it relates, a narrative account is an extension of one of their primary features." (Carr, 1986: 117) Tying "narrative" in this way to "real" structures and events limits it, however, to purposeful actions and to the aims, directions and closures respectively pursued, followed and established in those. Following such a reading, White's "narrativist" views represent little more than the imposition of story closures; at its most basic, the discussions that follow from this are then had largely

\footnotetext{
${ }^{12}$ For example, in "The Historical Text as Literary Artifact," and very quickly following the claims of history writing as a "translation" of fact into fiction and the idea of "invented and found," White somewhat confusingly defines "history" as "the real world as it evolves in time" (White, 1978: 98) rather than as the story we tell of it. In contrast, a helpful clarification of the distinction can be found in White (2013), for instance.

${ }^{13}$ Even someone as closely versed in White's thinking as Robert Doran appears to accept the disciplinary idea that there is something about realist form that makes it especially appropriate for history writing - or at least he repeats the common view that "the historian must strive for the most realistic presentation of historical reality possible, the kind of presentation that most effectively mirrors [...] its object" (Doran, 2013b: 111).

${ }^{14}$ This is not lost on White, who also notes the oftentimes practical "utility" of seeing history in this way, "for the definition of other types of discourse" (White, 1978: 89).
} 
in terms of a straightforward Aristotelian beginning-middle-end structure and the construction of basic story-points, provision of resolutions, and so on. More nuanced points of rhetorics and tropology and the broader, complex meaning of narrativity are largely ignored. (For explicit defences of these, see, for example, Partner, 2009 or Pihlainen, 2017.)

\section{From relativism to responsibility}

The frequent attempts to simplify White's thought might best be understood as aimed at defusing its potentially radical consequences. Strategies of limiting the reach of "fiction" to the inclusion of details that are superfluous to the "actual" history or presenting "narrative" as something that inheres in events and reality, for example, suggest relatively direct, supposedly "realistic" routes for minimizing the impact of theorizing history writing in terms of historians' creative role or, indeed, in terms of their ethical responsibilities. In this respect at least, White's suspicion that historians have little appetite for the considerations he raises - that, for them, "practice constitutes sufficient "theory" (a sentiment I cited at the outset) - appears quite justified. Beyond the examples already discussed, it seems that similar goals of domestication feature in efforts to present the consequences of a constructivist position on history writing in formal terms - at times even as calls for some straightforward replicability.

Efforts to systematize White were certainly discernible in the attention given to Metahistory: one of the key difficulties in its reception seems to have involved an undue formalism being attributed to White's thinking simply on the basis of the very brief and ostensibly structuralist Preface penned to it preceding publication. Even as sympathetic and close a reader of White as Frank Ankersmit, for example, presents White's discussion of tropology in Metahistory as a grid that White first introduces and then "applies" in the book (Ankersmit, 2009: 36). While such an interpretation is perhaps invited by White's preparatory introduction of the ideas, the systematicity and formalism that many readers would extend also to the overall treatment and analyses are not evident in the main investigations. ${ }^{15}$ Exactly how much the existence of the fairly easily appropriated Preface, Introduction and Conclusion to the book has influenced reception is difficult to estimate, but Spiegel, for one, has observed the relative lack of familiarity among historians with its details. Remarking on "the way in which Metahistory tended to be read; or more accurately not read," Spiegel notes "that most historians who turned to it for instruction in the 1970s and 1980s were inclined to read the Introduction and Conclusion and skip the intervening chapters" (Spiegel, 2013a: 494; see also the recent reappraisal of Metahistory's reception by Carolyn Dean [2019]). Considering that numerous commentators have labelled Metahistory a difficult read, this may indeed be the case, whether due to its "ambiguities" as well as White's supposed "love of technical terms" that led to "lack of 'resonance' within the community of historians," as Peter Burke (2013: 441) claims, or simply because of its frustrating "ability to evade or absorb thrusts" (Kellner, 1980: 2), for example. ${ }^{16}$

Already in the subtitle of the Introduction to Metahistory, White presents the idea of "the poetics of history" - an emphasis that can be assumed to have aggravated difficulties with reception in the same way as his comments on "fiction" discussed above. Similarly present here is the idea of history texts "considered purely as verbal structures" (White, 1973: 4). As with his more overt provocations, gesturing to "poetics" and textualism in these ways (or even, less alarmingly, to the "poetical and rhetorical elements" of history texts, as cited by Iggers [2000: 384]) can raise the spectre of some unbridled relativism - suspicion of which, as should be evident by now, is what drives much of the opposition to White's interventions. From a theoretical point of view this is not so easy to understand, however,

\footnotetext{
${ }^{15}$ In addition to often disclaiming the systematic nature of Metahistory, White is careful to remind that the formalizations he offers should not be taken as a "model" in any way (see, for example, White 2000: 391). For more on viewing the tropes of Metahistory as "models" or as "rigid and deterministic," see Paul (2011: 82-91) and Doran (2013a: 19-20) respectively; compare with Kellner (1980) and Vann (1998) who make these same arguments early on. The idea persists even in recent assessments of White's position, however, see, for example, Jörn Rüsen (2020: 95), who reads White as presenting this "scheme as an analytical tool" for mapping histories.

${ }^{16}$ Burke (2013) offers a concise summary of White's reception since Metahistory (and, equally succinctly, of White's place in the long tradition relating to the rhetorics of history). Of course, the reception of Metahistory has been discussed extensively; in addition to the sources mentioned already, see Ankersmit, 1998; Domanska, 1998: 173-175; and Jenkins, 1999: 126 ff. For a recent and more global approach to White's influence, see also Domańska, 2019.
} 
because when relativism is specifically named as the cause for concern it seems fairly easily dismissed. In responding to critique from Dirk Moses along these lines, for example, White presents his reasoning in just a few persuasive lines; and, important to note, this response also includes firm and rather obvious refutation of an earlier critique from Carlo Ginzburg and a number of other participants in the muchlauded "History, Event, and Discourse" meeting at UCLA in 1989. White says:

The first charge [levelled against him by Moses], which repeats the commonplace that relativism authorizes belief in, if it does not inevitably lead to, fascism (an argument mounted against me by Carlo Ginzburg), I simply reject. As far as I am concerned, cultural relativism can lead to many different ethical and political positions, but leads more often to tolerance and efforts to understand the other, rather than to intolerance, xenophobia, and fascism (White, 2005b: 337).

The critique from Ginzburg (1992) and others ${ }^{17}$ is commonly read by historians as bringing to light a substantial flaw in White's thinking, yet opposition to relativism on such consequentialist grounds seems relatively toothless and intended mostly as a scare-tactic. (Remember the basic idea from Rorty that meanings are not "out there" and, further, that believing they can somehow be found or discovered free of ideological construction is what in fact underwrites authoritarian attitudes.) Paul Roth rightly calls out the appeal to relativism in this fashion as an empty conceit, expected - as if by reflex reaction - "to bring any right-thinking person to their senses regarding White's brief against realist notions of historical representation." As such it is, he forcefully emphasizes, "just one more bogus move in a sterile debate" (Roth, 2019: 543).

Given the decades of back-and-forth over this very same issue, the annoyance expressed by Roth seems, to me too, eminently justified. This is even more so since the matter appears clear without appeal to the kinds of demonstrable consequences that White refers to in this response to Moses. Simply for purposes of thinking freely, thinking "for oneself" as it were, White's view of relativism looks to be the more defensible one. And he has made this very clear specifically with respect to the uses of history: "the socially responsible interpreter can do two things: (1) expose the fictitious nature of any political program based on an appeal to what 'history' supposedly teaches and (2) remain adamantly 'utopian' in any criticism of political "realism." (White, 1987: 227) According to this view of ethical societal engagement, proceeding on the basis of established practices and norms or, for instance, from an acceptance of "the way things are," precludes actively pursuing emancipatory or "oppositional" goals (for more on this, see Pihlainen, 2017; specifically on White's "liberation historiography," see Domańska, 2015 and Paul, 2011 ${ }^{18}$ ). Once again, our values are not "out there" to be found or discovered, already somehow formed and guaranteed by reality and close research into the facts - and if we assume this to be the case, we are acting in bad faith, shunning our ethical responsibilities. ${ }^{19}$

The somewhat puzzling, negative reaction to relativism has had significant impact on White's reception even among his supporters and, possibly as a result, interpretations of his philosophical commitments appear to be divided here too. Despite the clarity of the move from relativism to assuming responsibility in formulations like the one above, White has been read both as rejecting and as embracing postmodernism - and this "postmodernism" has been given wildly differing meanings. ${ }^{20}$ More obvious

\footnotetext{
${ }^{17}$ For details, see Friedländer, 1992; Friedländer's introduction to the volume is also reprinted in Jenkins, 1997. A recent discussion of the accusation of fascist tendencies made against White in this debate can be found in Dean, 2019: 1346-1347.

${ }^{18}$ Verónica Tozzi summarizes the political charge relating to this well: "in matters of political or moral adequateness of our uses of the past, no precision in facts or evidence can help us, precisely because we are dealing with political or moral dissent. This does not imply that we should accept any political conclusion allegedly drawn from historical reconstructions" (Tozzi, 2009: 269),

${ }^{19}$ This is of course a broad point, extending well beyond the discourse of history. In a masterful reading of poststructuralism and its resistance of the inertial authority of the status quo, Sande Cohen articulates the difficulty of such realist beliefs well, noting the ethical lack in discourse and thought "when one 'knows,' in advance, what things 'look like,' [which leads to] the emergent [being] pressured and forced to fit with and conform to the already-existing weight of already-known sign-systems." (Cohen, 1993: 120) This realist expectation "authorizes," he reminds, "a present-subject to absorb contradictory appearances, validating authority as a figure that separates essential predicates from unessential ones without owning up to what is occurring." (Cohen, 1993: 120) With respect to history, hiding behind professional methods and practices or the assumed "authenticity" of stories permits this same evading of responsibility.

${ }^{20}$ White justifiably describes some of these readings of postmodernism critically. Marwick's use of the term, for example, he calls "so bizarre and uninformed" as to render discussion regarding the problems he attributes to it pointless (White, 1995: 233). Importantly, this is no underhanded rhetorical strategy: in his criticism, Marwick disturbingly equates "metahistory" and, by correspondingly strange
} 
attacks often repeat the supposedly clever idea that, in refusing foundations and foundational statements, postmodernism involves itself in a performative and self-defeating contradiction. This flippant claim simply ignores long-standing and well-justified philosophical positions with respect to scepticism and agnosticism regarding knowledge. Hand-in-hand with this accusation are presented also the perceived deleterious consequences of accepting anti-foundationalism - a fear that Gertrude Himmelfarb expressed in rather remarkable fashion: "Postmodernist history, one might say, recognizes no reality principle, only the pleasure principle - history at the pleasure of the historian." (Himmelfarb, 1997: 158; a handy and very illuminating introduction to many of these debates is provided by The Postmodern History Reader collected by Jenkins [1997].) Even setting aside the crass way in which this claim ignores all of the disciplinary commitments expressed by "postmodernists" like White, the implied "anything goes" position is clearly at odds with his sophisticated and expressly ethical understanding of relativism: "I conceive relativism to be the basis of social tolerance, not a licence to 'do as you please." (White, 1987: 227).

Conceivably, it is this imprecise articulation of relativism with "postmodernism" seen as radically nihilist and ultimately destructive that is also reflected in the resistance to more meticulous poststructuralist and antifoundationalist arguments for relativism even by a number of defenders of White's overall position. While White's affiliation with postmodernism can certainly be debated - not least on the basis of his own contradictory statements about $i^{21}$ - his view of the consequences of relativism is unambiguous. Because of the range of positions White seems to occupy, attempting to definitively capture him in such terms is not the most urgent task, however. More important, going forward, will be to examine how these various commitments contribute to his overall views about history and the role of the historian.

A key move in understanding the nature and ramifications of White's relativism involves trying to negotiate between his existentialist affinities and his poststructuralist commitments. Commentators who see White as fundamentally an existentialist have tended to reject poststructuralism, which they read as involving the acceptance of a meaninglessness that frustrates future-oriented action (see, for example, Kellner [1980: 17], for whom White's "emphasis on choice [...] is repeated unmistakably" as he "persistently asserts human freedom" in a Sartrean fashion; also see Paul [2011]; Doran [2013a, 2013b]; and Spiegel [2013a]). When reading poststructuralism not only as a scene of endless slippage of meaning but also, and relatedly, as an opening up of a space for the assumption of ethical-political responsibility (in line with White's interpretation of relativism), the overlap and continuity between existentialism and poststructuralism regarding "choice" and "decision" is evident, however: on the one hand, there is refusing to act in "bad faith" in the Sartrean sense and instead assuming the responsibility to choose; on the other, there is the moment of facing the aporia and taking the "undecidable decision" $a$ la Derrida. ${ }^{22}$

Once we broaden our reading in this way and see White also as a poststructuralist and thus in terms of the accompanying decisionist ethic, his defence of relativism as a route to responsibility appears as a

extension, postmodernism with, of all things, speculative or substantive philosophies of history. Ankersmit (1998: 185) later took an equally stern view of Marwick's interjection, describing it as "a perfectly inane and silly tirade." Somewhat gentler responses pointed to the pronouncedly "imprecise terminology" (Kansteiner, 1996: 215) and the lack of common vocabulary that caused participants in this debate to largely "run inconsequential rings around each other" (Southgate, 1996: 209).

${ }^{21}$ Citing him from an interview in 1994, Dean (2019: 1343), for instance, claims that White "did not think of himself as postmodern" (on that occasion, White self-identified instead as "a formalist and a structuralist"). Comments have, however, ranged from denials of White's postmodernism (for example, Doran, 2013b: 110) to viewing his work as a "highly original adaptation of the postmodern challenge" (Kansteiner, 2000: 226-227). In Richard Vann's reading, White moved away from his stance of "existential humanism" soon after Metahistory (Vann, 1998: 144) - something that may also explain the contrasting views. By 2005, however, White appears comfortable claiming the label for his core argument: "the anti-postmodernist handwringers are wrong when they say that the postmodernists are 'against' history, objectivity, rules, methods, and so on. What we postmodernists are against is a professional historiography, in service to state apparatuses that have turned against their own citizens, with its epistemically pinched, ideologically sterile, and superannuated notions of objectivity" (White, 2005a: 152, my emphasis). For a good discussion of White's later "pessimism" regarding academic history practices, see also La Greca, 2016.

${ }^{22}$ For a brief introduction to this reading of Derrida, see, for example, Jenkins [1999: $1 \mathrm{ff}$.]. Citing White's early work, Kellner interestingly reproduces a definition of existentialism that could be applied equally to Derrida's arguments for ethical-political responsibility (but so often lost to those who read him as a self-defeating nihilist): "the one crime that the individual can commit against himself [...] is unwillingness to accept responsibility for his acts and ascription of this personal responsibility to something outside the self" (Kellner, 1980: 17). 
self-evident strategy - and one that is very much in line with other poststructuralist ethical-political approaches. In this, it seems important to rely on readers of White like Keith Jenkins, Sande Cohen or Wulf Kansteiner, for example, who demonstrate a more generous and radical understanding of poststructuralism in its ethical mode. Understood in this context, a Whitean constructivist position can be seen to refute predefined norms and foundations for choices and actions. This recognition of the fundamental meaninglessness "out there" is the insight that can, White argues, lead people "to endow their lives with a meaning for which they alone are fully responsible" (White, 1987: 72). Through facing the inevitable lack of certainty in making our decisions, we are drawn into an ethical stance and presented with a call to assume responsibility for the future with each and every choice.

\section{References}

Ankersmit, F. (1998). "Hayden White's appeal to the historians". History and Theory. 37(2). 182-193.

Ankersmit, F. (2009). “White's 'new neo-Kantianism': Aesthetics, ethics, and politics”. In F. Ankersmit, E. Domańska \& H. Kellner (Eds.). Re-figuring Hayden White. Stanford University Press. Stanford. 3453.

Ball, K. \& Domańska, E. (2019). "Hayden White". In Oxford Bibliographies in Literary and Critical Theory. Retrieved from https://www.oxfordbibliographies.com/view/document/obo9780190221911/obo-9780190221911-0084.xml

Burke, P. (2013). "Metahistory: Before and after”. Rethinking History. 17(4). 437-447.

Carr, D. (1986). "Narrative and the real world: An argument for continuity". History and Theory 25(2). $117-131$.

Chartier, R. (1997). On the edge of the cliff: History, language, and practices. (L. G. Cochrane, Trans). Johns Hopkins. University Press. Baltimore.

Cohen, S. (1993). Academia and the luster of capital. University of Minnesota Press. Minneapolis.

Dean, C. J. (2019). "AHR reappraisal: Metahistory and the resistance to theory" [Review of the book Metahistory: The historical imagination in nineteenth-century Europe. by H. White]. The American Historical Review. 124(4).1337-1350.

Domańska, E. (1998). "Hayden White: Beyond irony”. History and Theory. 37(2). 173-81.

Domańska, E. (2015). "Hayden White and liberation historiography”. Rethinking History. 19(4). 640650 .

Domańska, E., La Greca, M. I. (Eds.). Roth, P. Chen X., Tozzi Thompson, V. \& Pihlainen, K. (2019). "Globalizing Hayden White". Rethinking History. 23(4). 533-581.

Doran, R. (2013a). Editor's introduction: "Choosing the past: Hayden White and the philosophy of history”. In R. Doran (Ed.). Philosophy of history after Hayden White. Bloomsbury. London. 1-33.

Doran, R. (2013b). "The work of Hayden White I: Mimesis, figuration and the writing of history". In N. Partner \& S. Foot (Eds.). The SAGE handbook of historical theory. Los Angeles. SAGE. CA. 106-118.

Fillion, R. (2019). [Review of the book The work of history: Constructivism and a politics of the past, by K. Pihlainen]. In International Network for Theory of History online reviews. Retrieved from https://www.inth.ugent.be/content/work-history-constructivism-and-politics-past 
Friedländer, S. (Ed.). (1992). Probing the limits of representation: Nazism and the "final solution." Harvard University Press. Cambridge.

Geertz, C. (1973). The interpretation of cultures: Selected essays. Basic Books. New York.

Ginzburg, C. (1992). Just one witness. In S. Friedländer (Ed.), Probing the limits of representation: Nazism and the "final solution". Harvard University Press. Cambridge. 82-96.

Himmelfarb, G. (1997). Telling it as you like it: Postmodernist history and the flight from fact. In K. Jenkins (Ed.) The postmodern history reader. Routledge. London. 158-174.

Iggers, G. G. (2000). "Historiography between scholarship and poetry: Reflections on Hayden White's approach to historiography". Rethinking History. 4(3). 373-390.

Jenkins, K. (1997). The postmodern history reader. Routledge. London.

Jenkins, K. (1999). Why history? Ethics and postmodernity. Routledge. London.

Jenkins, K. (2008). “'Nobody does it better': Radical history and Hayden White”. Rethinking History 12(1). 59-74.

Jenkins, K. (2009). “'Nobody does it better': Radical history and Hayden White”. In F. Ankersmit, E. Domańska \& H. Kellner (Eds.). Re-figuring Hayden White. Stanford University Press. Stanford. 105123

Kansteiner, W. (1996). "Searching for an audience: The historical profession in the media age - A comment on Arthur Marwick and Hayden White". Journal of Contemporary History. 31(1). 215-219.

Kansteiner, W. (2000). "Mad history disease contained? Postmodern excess management advice from the UK". History and Theory. 39(2). 218-229.

Kellner, H. (1980). “A bedrock of order: Hayden White's linguistic humanism”. History and Theory. 19(4) 1-29.

La Greca, M. I. (2016). "Hayden White and Joan W. Scott's feminist history: The practical past, the political present and an open future". Rethinking History. 20(3). 395-413.

Momigliano, A. (1981). "The rhetoric of history and the history of rhetoric: On Hayden White's tropes". In E. S. Shaffer (Ed.). Comparative criticism: A yearbook. Vol. 3. Cambridge University Press. Cambridge. 259-268.

Partner, N. (1998). "Hayden White: The form of the content". History and Theory. 37(2). 162-172.

Partner, N. (2009). "Narrative persistence: The post-postmodern life of narrative theory". In F. Ankersmit, E. Domańska \& H. Kellner (Eds.) Re-figuring Hayden White. Stanford University Press. 81104.

Paul, H. (2011). Hayden White: The historical imagination. Polity. Cambridge.

Pihlainen, K. (2013). "The work of Hayden White II: Defamiliarizing narrative”. In N. Partner \& S. Foot (Eds.) The SAGE handbook of historical theory. SAGE. Los Angeles. 119-135.

Pihlainen, K. (2017). The work of history: Constructivism and a politics of the past. Routledge. New York. 
Pihlainen, K. (2019a). "The possibilities of 'materiality' in writing and reading history". História da Historiografia 12(31). 44-81.

Pihlainen, K. (2019b). "Why call it constructivism if all it does is question?" In E. Domańska \& M. I. La Greca (Eds.) Globalizing Hayden White (564-569; 580-581). Rethinking History 23(4). 533-581.

Roberts, D. D. (2013). "Possibilities in 'a thoroughly historical world': Missing Hayden White's missed connections". History and Theory. 52(2). 265-277.

Roth, P. A. (2019). "What is to be done?” In E. Domańska \& M. I. La Greca (Eds.) Globalizing Hayden White. (540-546, 573). Rethinking History. 23(4). 533-581.

Roth, P. A. (2020a). "An audience for history?" [Review of the book The work of history: Constructivism and a politics of the past. by K. Pihlainen]. Journal of the Philosophy of History 14(1). 81-92.

Roth, P. A. (2020b). The philosophical structure of historical explanation. Northwestern University Press. Evanston.

Rüsen, J. (2020). "A turning point in theory of history: The place of Hayden White in the history of metahistory". History and Theory 59(1), 92-102.

Southgate, B. (1996). "History and metahistory: Marwick versus White". Journal of Contemporary History 31(1). 209-214.

Southgate, B. (2003). Postmodernism in history: Fear or freedom? Routledge. London.

Spiegel, G. M. (1997). The past as text: The theory and practice of medieval historiography. Johns Hopkins University Press. Baltimore.

Spiegel, G. M. (2013a). "Above, about and beyond the writing of history: A retrospective view of Hayden White's 'Metahistory' on the 40th anniversary of its publication". Rethinking History 17(4). 492-508.

Spiegel, G. M. (2013b). "Rhetorical theory/theoretical rhetoric: Some ambiguities in the reception of Hayden White's work". In R. Doran (Ed.) Philosophy of history after Hayden White. Bloomsbury. London. 171-182.

Spiegel, G. M. (2019). "The limits of empiricism: The utility of theory in historical thought and writing". The Medieval History Journal 22(1). 1-22.

Tozzi, V. (2009). "Figuring the Malvinas war experience: Heuristic and history as an unfulfilled promise" (Moira Pérez, Trans.). In F. Ankersmit, E. Domańska \& H. Kellner (Eds.), Re-figuring Hayden White. Stanford University Press. Stanford. 261-281.

Tucker, A. (2001). "The future of the philosophy of historiography". History and Theory. 40(1). 37-56.

Vann, R. (1998). "The reception of Hayden White". History and Theory. 37(2). 143-161.

Waites, B. (2011). "In defence of historical realism: A further response to Keith Jenkins". Rethinking History. 15(3). 319-334.

White, H. (1973). Metahistory: The historical imagination in nineteenth-century Europe. Johns Hopkins University Press. Baltimore.

White, H. (1978). Tropics of discourse: Essays in cultural criticism. Johns Hopkins University Press. Baltimore. 
White, H. (1987). The content of the form: Narrative discourse and historical representation. Johns Hopkins University Press. Baltimore.

White, H. (1995). "Response to Arthur Marwick”. Journal of Contemporary History 30(2). 233-246.

White, H. (2000). “An old question raised again: Is historiography art or science?" (Response to Iggers). Rethinking History. 4(3). 391-406.

White, H. (2005a). "Introduction: Historical fiction, fictional history, and historical reality". Rethinking History. 9(2-3). 147-157.

White, H. (2005b). "The public relevance of historical studies: A reply to Dirk Moses". History and Theory 44(3). 333-338.

White, H. (2009). "Foreword: The postmodern messenger". In K. Jenkins, At the limits of history: Essays on theory and practice. Routledge. London. 1-3.

White, H. (2013). Comment. In Robert Doran (Ed.), Philosophy of history after Hayden White. Bloomsbury. London. 209-213.

White, H. (2014). The practical past. Northwestern University Press. Evanston.

White, H. (2017). Foreword. In. K. Pihlainen. The work of history: Constructivism and a politics of the past. Routledge. New York. ix-xii. 